\title{
Appearing the motivation of culture research through developing the Minangkabau culture subject based portfolio model
}

\author{
Muhiddinur Kamal ${ }^{1}$, Z. Mawardi Effendi ${ }^{2}$, Firman ${ }^{3}$, Taufina Taufik ${ }^{4}$ \\ ${ }^{1234}$ Universitas Negeri Padang, Padang - Indonesia,
}

\begin{abstract}
The goals of this research are 1). To Develop the learning of BAM in portofolio based model in Islamic Junior High School, 2). To test the validity, practicality and the efectifity of the developed learning. This research was done by using research and devepment (R\&D) research, by using Mc Kenny development which was adopted by Plom. There were three phases to design this research: prelimanary research, design and evaluation. To apply the development of learning in the classroom, the researcher designed the teacher's book, the student's book, the guide book and also the validity testing, practicality and the efectivity of the book which is refering to the designed of learning. In the process of the research, the qualitative data was collected throug observation, interview and field note. Meanwhile, in quantitative data was collected throug test and question. Then, the research did the data analisis and the final learning development of Minangkabau Culture Lesson (BAM). The result of the research were: a). The development of the learning of BAM in portofolio model which was developed in the form of guide book model, and learning device the teacher's book and the student's book. b). The user of the learning development of Minangkabau Culture Lesson (BAM) in portofolio based emperically can in crease the student's motivation in learning.
\end{abstract}

Keywords: local wisdom, minangkabau culture subject, model, portfolio

\section{Introduction}

Indonesia is one of the countries with low production of good researches bothit;the regions of Asia and in the regions of South east Asia. The number of researches and scientific publications in Indonesia is lower than those of other countries with less known academic and scientific world such as Malaysia and Pakistan. Research findings from SCImago (in Kompas 9112/2010) ranked Indonesia in the 64th position of 234 countries surveyed. The number of scientific and research publications in Indonesia for 12 years period only reaches 9149 documents.It is lower than Pakistan, in 50th position.

Publication of scientific researches in Indonesia is also lower than those of neighboring countries such as Singapore, Malaysia, and Thailand. Singapore is 3151 position, Thailand 43thand Malaysia48th. Seen from the previous time, many Malaysian studied the science of research to universities in Indonesia such as ITB Bandung, UGM. Lately, the three ASEAN countries above have continued in creasing the quantity of their scientific publications while Indonesia as showed different trend. Indonesia is much lower than 
Japan, which publishes 1.2 million researches, thereby making it in 3rd position in the world .At the top position is the Unites States, which publish es4.3millionresearches.(Kompas,9112/2010).

Research culture in Indonesia, which is insufficient, is believed to be one of the leading factors that make Indonesia lag behind other countries in scientific publications. Low motivation to conducta research often becomes as tumbling block for Indonesia to competein the interational world. It is inevitable fact that the researches produced by most education al institutions are not significant.The phenomena of low interest in research and the low number of scientific publications has brought many attentions and debate dint he last decade. Its hould be studied extensively especially fie educational institutions that bear re sponsibility for this.

Scientific research is a senes of accumulated observations that eventually brings up a theory to explain and forecast the occurring phenomena. The research is able to uncover phenomena and secrets of nature that need to be studied and researched. Thus, research is a very important part in academic life as its academic in nature as well as enable academia to show their dedication to the community in order to help it find the solution for its problems. In addition, it also allows them to bring new inventions for humanity. Educational institutions are expected to beable to develop a research as the part of academic institution. (http://ncips- wordpress.com accessed onMarch 29,2015)

Research culture in Indonesia to advance the scientific world is still lacking in its contribution to scientific development. This situation is very alarming forth is nation in its course to face an increasingly complex world competition. Researchs kills should be fostered and nurture don learners since their early age because these skills are related to their learning process, especially reading and writing. Without writing, there search finding swill not beavailable for the community. Learners who like doing a research will gain new knowledge and intelligence to answer all the challenges of life and to have a ri chimagination.

In so mecases of the learning process, there are various is suesthat need to be considered by academics in order to make the learning process be able to foster students' research in learning.Students' motivation in the learning process is commonly low.

Students' low motivation is also caused by external factors such as the in appropriate e learning model used by teachers in the learning process. Teachers pay less attention to the principles of learning in fostering students motivation, Interests, and creativity to learn and to overcome their difficulties. The learning process seems to have been don e well because the materials outlined in the syllabus have been presented in accordance with the allocated time.

\section{Theoritical Review}

\section{Participatory Portfolio-Based Learning Model}

The word model implies the meaning "a pattern, a style, an example, are reference, a variety of things that will be created orgenerated" (BalaiPustaka,2001:751). However, the meaning of model use din this study is"apattern or as tyle of learning that is created, produced, and used for the successful program of teaching and learning activities."

Model can be defined as a conceptual frame work that is used as a guideline in conducting an activity (Suherman,2003:37). The learning model can be understood from the definition proposed Joyce and Weil (1980:1): "A models of teaching is a plan or pattern that can be used to shape the curriculum (long term courses of studies),to design instructional materials, and to guide instruction in the classroom and other settings".In line with the above definition, Eggen, Kauchak,and Harder(1979: 12)

Generally, portfolio is a sample collection of one's work (students) that is knowingly submitted so as to providean overview of theirability and development within acerta in period of time(Subandar:IT). Arnie (2015: 47) describes portfolio is derived from the English "portfolio" which means a document to a letter. The definition portfolio in this study is a collection of students' works for a particular purpose that are selected through the prescribed guidelines. Each portfolio contains selected works of one-class 
students who have cooperatively worked, identified, collected, processed, and analyzed data in order to find the solution for the studied problem.

According to Arnie (2015: 98) There are several advantages of portfolios use in learning: (1) Encouraging collaboration (communication and relationship) between students and students as well as between students and teachers. (2) Allowing teachers to asses students ability in making report and in writing and producing various academic tasks and to develop students' insight about the studied problems. (3) Educating students to have the ability to make reflection on their learning experience. (4) Preserving students' learning memory since they have performed a series of learning activities from knowing, self-comprehending, conducting activities, and cooperating with others

Popham (1995) suggests several advantages the use of portfolios: "(1)give students the opportunity to assess their task development and the their learning outcomes, (2)able measure the learning achievement of each student with different characteristics from each other, ( 3) use a collaborative assessment approach, (4)conduct self-assessment (5)aim to increase efforts, works and achievement, and(6)interrelate the assessment and the teaching process".

Furthermore, Arnie (2012: 45) states that the portfolio-based learning allows students to; (1) practice combining the concepts the teachers' explanation or books / reading material along with their applicability in daily life,(2)seek information outside the classroom in the form of reading bundles, experiences, direct objects, TV/radio (internet) orpersons /experts /leaders, (3)create alternative solutions to the topic of the object discussed, (4)make a decision (suitable to their capabilities) that associated with the concept that they have learned (5) formulate steps to be taken to address the problem.

Thus, the portfolio-based learning provides a diversite learning resources and more flexibility for students to select appropriate learning resources as the foundation to study natural or societal phenomena. It is in accordance with one of the principles in the competency-based curriculum development, which is centered on the students as the developer of knowledge. It means the effort to build students' autonomy to learn, collaborate,help their friends, make observations and self assessments for a learning reflection, which will encourage the mtobuilda learning portfolio of learning.

In addition to providing the democratic laboratory, portfolio learning model also aims to help students learn how to express their opinion and solve the problem. This activity invites students to cooperate with their classmates through the assistance of teachers and other volunteers to achieve the followingtasks:1). Identifythe problem to bestudied. 2).Collecting the information. 3).Assessing the problem solving 4).Proposing the problem solving 5).Presenting the showcase 6)Formulating the action plan.(Budimansyah,2001:7-8).

2. Nature ofResearch

McMillan and Schumacher state "research is as systematic process of collecting and analizing information(data)for some purposes"(1984:4). Research is a systematic process of collecting and analyzing information purposes. Tuckman explains: "Research IS a systematic attempt to provide an swers to the question"(1972:1).From the definition above, it can be inferred that research asisan temptora systematic process to collect data and later process the mfora specific purpose such as for problem solving.

Furthermore, McMillan and schumacher explain:"Research methods that is the way one collects and analyzes the data-were developed for acquiring knowledge by reliable and trustworthy procedures. Regarding to Research method, it is the way of how someone collect and process data that they develop to acquire knowledge or an answer to the problems. Moreover, McMillan and Schumacher describe the scientific procedures as a series of process involving the steps as follows:1) Recognize and define are search problem, 2) Review of existing knowledge on the problem, 3) State are search questionor hypothesis, 4) Determine the design to Investigate the question ortest the hypothesis, 5) Collecting data, 6)Analyzedata, 7) Interpret the results order to draw conclusions about the research 
problem.The research aims to discover, to develop, orto test the truth of knowledge (Sutrisno Hadi, 1989: 3).Research with the goal of invention (explorative) means attempting to gain knowledge about something that has not been discussed or studied by people. Development means the research don eas. the development or the follow up of the previous studies. The research also aims to examine the truth (verificative) about the previously conducted research done.

Sutrisno (2013:8) proposes the following steps involved in the process of research: 1)Identifying the object or subject of the problem, 2). Limiting the object or subject of the problem, 3). Collecting data or information, 4). Processing data and draw conclusions, 5).Formulating and reporting the findings, 6).Suggesting research implications.

On the other hand, Tuckrnan (1972: 12)suggests several research steps as follows: 1).Identifying aproblem, 2). Constructing hypoyhesis,3). Identyfing and labeling variables, 4). Constructing the operational definition, 5).Manipulating and controlling variables, 6). Constructing a research design, 7).Identyfing and constucting devices for observation and measurement, 8). Constructing quetionnaire and interview schedules, 9) carryng out statistical analysis, 10) Using the computer for the data analysis, 11).Writing are search report.

Thus, it can beunderstood that theresearch isascientific activity that is conducted through collecting data scientifically to address a problem thatrequires anasolution.

\section{Method}

This research is research and development $(\mathrm{RnD})$. It is a kind of research with the aim to yield a certain product and test its effectiveness. In this present research, the development model used is adapted from McKenny model. This model consists of three main phases: (1) preliminaryresearch, (2) prototyping phase, and (3) assesment stage (Plomp dan Nieveen, 2007: 15).

The testing subject in this research is 9th grade students in MTS Koto Tuo Kumpulan Pasaman Regency. This inclusion criteria to select this subject are: 1) this madrasah (islamic school) is one of the schools with high integrity receiving award from Ministry of Education, 2). One of the oldest madrasahs in Pasaman regency, 3). The unavailability of developed of instructional material using portfolio model.

The types of data used in this research are qualitative and quantitative data. Qualitative data were obtained from discussion, observation, interview with teachers and students as well as field notes. Quantitative data were obtained from the results of questionnaire, observation sheet, and observation on students' character. The data obtained from many instruments were analyzed descriptively, qualitatively, and quantitatively in order to identify whether the developed instructional materials are valid, practical, and effective.

\section{Result and Discussion}

The achievement of this research is associated with the aspects of validity, practicality, and effectiveness from the developed instructional materials as well as its relationship with socio-cultural research.

1. Development of BAM Learning Using Portfolio Model.

The developed model is instructional materials for BAM learning using portfolio model. The learning activities are conducted in sequential steps starting from identifying the problem to be studied, collecting the information, assessing the problem solving, proposing the problem solving, presenting the show case, and formulating the action plan. Such learning can maximize students' ability in the activities of identifying, recognizing problems in the field, collecting information, cooperating in studying problem solving, thinking about how to solve the problems, having responsibility through show case, and thinking how to take an action. This developed BAM learning model has been 
validated. The results show that the developed model has fulfilled the criteria valid, practical, and effective.

\section{Validity}

Based on the results of validity test in the previous chapter, it is found that prototype or learning development has fulfilled the criteria of validity, although it is not fulfilled simultaneous. The aspects that have not been valid at the start of the test are related to a number of activities designed and the assumption of students' learning process conducted not as it is expected. The previous designed activities do not lead to the more effective learning. A revision is conducted by looking at the activities made during the learning process. The revised results have an impact on the development process of the instruments used.

The product validity test results show that the research product is feasible to be used, then tested in the next research stage. Some of the arguments supporting the validity test of this research are: Firstly, the findings of this study show that the research product has fulfilled the fundamental aspect of the product development i.e the logical consistency between the expected product (the Expert result) and the produced product (the result of the field test). This result is in linewith Nieveen's opinion in Plomp (2013), a product designed to show a logical consistency between product expectations and result. Expectation means that the product will be used, the actual and result means that the product has been able to be used.

Secondly, the validity test results have also described the use of technical evaluation of products proposed by Tessmer (1994) namely expert review, focus group discussion, one to one, small group, and field test. According to Tessmet (1994), the product assessed by the expert validation has a better level than other products, but the product validated by the expert will still be revised at the stage of FGD, one to one, small group, and field test so that the product has a stronger resistance.

\section{Practicality}

Based on the above description, validators' predictions and assessments declare the product eligiblity to be applied in the classroom. Based on the test results, the product can make students learn BAM with interesting and fun. This can be seen from students' activities in searching and collecting information, reviewing issues, presenting and doing show cases through learning activities that require students to interact, with fellow students, teachers and the community environment. This is in accordance with Vigotsky who states that the intellectual development of children driven by the interaction of fellow students. This reinforces and explores the findings of Asep Suryadi, (1997), Riswan Jaenuddin (1999), Sundarie Fauzie (2003), Irawan Wahyono (2003), Ine Kusuma Aryani (2002), who stated that portfolio learning can increase student motivation and participation in learning.

It has been described previously that portfolio-based learning always begins by identifying existing socio-cultural problems that exist in of society. It then goes with participative, by searching and collecting information, discussing to study problem, and work to prepare show case and do reflection.

Portfolio learning based model generally followw the principle of activity-based learning. This is reflected in the involvement of students in various activities such as seeking and multiplying information, discussing, asking questions, answering questions with multiple solutions, explaining and arguing the results of answers and accountability. This kind of learning is in line with what Jawirksky (1995) proposes that teachers should give students the opportunity to acquire self-built knowledge so that they are able to account for the knowledge construction outcomes. Students' activity at the beginning of learning is rather stiff. Such Conditions are understandable because this kind of learning has never been applied and is very different when compared to the previous learning.

From the teacher side, portfolio-based learning model has motivated the teacher to apply it. This is seen in the learning process undertaken by teachers becoming better after using this developed model. The results of interviews with teachers also reveal that teachers feel more happy and challenged in managing learning. Increased teacher's creativity will certainly improve students' motivation in the learning process.

\section{Effectiveness}


The effectiveness of the product can be seen from several aspects: 1) Students' reaction. In this case, it consists of several questions: whether students like the BAM learning books that have been used, whether the time spent is sufficient and efficient, and whether the book is useful; 2) Students' learning activity, whether the students know what kind of knowledge is expected; 3) students' ability to use knowledge and skills; 4) Student performance. What is the impact of the product on student performance. Performance includes self-confidence, ability to be creative and active, and 5). Motivation

The students are eager to work because the activity is designed to be directly related to everyday life. In the learning process, students do activities, so they gain knowledge as expected. It will lead to better motivation. Students' performance such as self-confidence, reasoning, activity, creativity, and motivation are generally better after portfolio based model BAM learning is used. It indicates that the resulting product is effectively used, meaning it has a high effectiveness.

After the experiments, a variety of phenomena are found. Students have generally shown satisfactory results in the learning process, students perform a series of activities. They involve themselves in a participatory way. Students complete learning activities with portfolio model steps. This means that students have high motivation to follow thelearningprocess.

5. Relevancy ofPortfolio-based Learning Model with Social Research

Participatory portfolio-based plearning modelisa learning model with emphasis on students's kills toseekand find the learning and on functioning learning members with mutual effort and responsibility to assistand to maximize the leaming process. It also mentioned by Muhammad Faiz Zaki (2009) who states that portfolio-based learning in the form of the best students' work collection will foster students' attitude to act with responsibility. (Http://penelitiantindakankelas. blogspot.com.12009)

Therelation ship between portfolio learning model and the research is that there a resome similar in both processes. Besides, portfolio-based learning model in practice situates students to interact with other students and community, inwhich teachers area bleto organize the learning materials and assignments the form of port folio inorder that students can understand do the task with their group. In addition, portfolio also contains the learning process inthe form portfolio display that enable to train students to dothe research and defend its findings in public. Wakhiuddin (2009) states that a collection of records and documentations produced by the students is a form of their good achievement in the learning process.(Http://wakhiuddin.wordpress.com.2009).

Through portfolio learning, students are expected to achieve the learning outcomes that are divided into five groups: intelectual skill,cognitive strategy, verbal information, motor skill and attitude. Portfolio-based learning method can also train students to have the skills, both thinking skills and social skills such as thes kill to express opinions, to receive advice and input fromothers, towork together, tonurture asense of solidarity, and tominimize the occurrence of disruptive behavior in the classroom (Stahl: 1994).

Portfolio-based learning model provides a large opportunity for students to explore their knowledge. They can search for learning resources on their own from their environment either from the media or from the surrounding environment. This learning model is also more flexible for student to work in the form of portfolio and to discuss with both fellow students and teachers aslearning advisors because students will perform their through presenting it. In addition, students will have many opportunities to exchange information, expenences, opimons and problem solving formally/orally i.e. face to face interaction, so this method is able to enhance good communicative skills that will influence their interest to conduct a research mentions:" the models are prescriptive teaching strategies designed to Accomplish particular instructional goals. They are prescriptive in the sense that the teacher's responsibilities during the planning stages... implementing and evaluating a teaching model, then canbe Consideredas atypeofblueprintforteaching".Thestatementsaboveillustratesthatthe learningmodeli the instructional blue print engineered so as to achieve certain goals of teaching.

Generally, portfolio is a sample collection of one's work (students) that is knowingly submitted so as to provide a noverview of the irability and development within a certain period of time (Subandar:IT). 
Arnie (2005: 47) describes portfolio is derived from the English "portfolio" which means a documen toraletter. The definition port folio in this study is a collection of students' works for a particular purpose that a reselected through the prescribed guidelines. Each port folio contains selected works of one-classs tudents who have cooperatively worked, identified, collected, processed, and analyzed data in order to find the solution for the studied problem.

Bartonand Collins(1997) in Sumama(2006: 25) states that the object of the portfolio (evidence) are classified into four types : a. Artifactsi students' works that they door produce in the classroom, $b$. reproduction l.e. students' works they do outside the class room, c. attestationsi .e. teachers' statementsor observations about the students, d. productioni.e.students' works that are especially prepared for the portfolio.

\section{Conclusion}

The implementation of BAM learning using portfolio based model has an impact on the changing role of teacher, from teacher center to student center. It occurs because the learning process requires to explore students' activities. Students' positive attitudes are explored by opening the lessons interestingly, creating a democratic learning atmosphere, and applying a number of rules in conducting activities. Portfolio learning model can stimulate both mental activity and physical activity.

\section{References}

Ahmadi, Iif Khoiru,dkk (2012). Mengembangkan Pembelajaran Berbasis Keunggulan Lokal. Jakarta: Prestasi Pustaka.

Al-Muchtar, Suwarma. (2014). Pengembangan Berfikir dan Nilai dalam Pendidikan. Bandung: Gelar Pustaka Mandiri.

FajarAmi.(2015).Portofolio Dalam Pembelajaran IPS.Bandung: Alfabeta

Hosnan (2014). Pendekatan Saintifik dan Kontekstual Dalam Pembelajaran Abad 21. Bogor : Galia Indonesia.

Majid,Abdul (2014). Pembelajaran Tematik Terpadu. Bandung: Remaja Rosdakarya

Taufik, Taufina \& Muhammadi. (2011). Mozaik Pembelajaran Inovatif. Padang: Suka Bina Press

Eriawan Kamil. Model Pembelajaran Portofolio Kewarganegaraan.

http://EriawanKamil.Woodpress.com 